\author{
Huszthy Alma \\ Eötvös Loránd Tudományegyetem \\ huszthy.alma@gmail.com
}

\title{
TANÁRI BESZÉD A KÖZÉPISKOLAI OLASZÓRÁN: ÁLTALÁNOSÍTHATÓ SAJÁTOSSÁGOK ÉS EGYÉNI STRATÉGIÁK ${ }^{1}$
}

\section{Bevezetés}

A kommunikáció - az emberi kapcsolatok egyik nélkülözhetetlen mozzanata (Vörös 2004: 395) - fontos szerepet tölt be az osztályteremben is. A nyelvtanárok számára külön kihívást jelent, hogy a diákok anyanyelvétől eltérő nyelven kell kódolniuk üzeneteket. A célországon kívüli, így a magyarországi közoktatásban a nyelvtanár leggyakrabban nem anyanyelvi, ez pedig tovább bonyolítja a helyzetet: az idegennyelv-tanárnak egy sor olyan döntést kell meghoznia, amelyek meghatározzák tanári kommunikációját. Nem véletlen, tehát, hogy az olaszos szakmódszertani kurzusaimon a hallgatók, a jövő olasztanárai gyakran teszik fel nekem a következő alapvető, mégis kicsit kényes kérdést: Milyen nyelven kell majd tartanunk az olaszórákat a gimnáziumban?

Ez akár egy meglepő kérdés is lehetne, de nem is annyira könnyű válaszolni rá. Egyrészt mert nem anyanyelvi olasztanárokról van szó, másrészt az olaszt második idegen nyelvként átlagosan heti 3-4 órában tanítjuk.

Ebből a problémából kiindulva a tanulmány célja, hogy bemutassa a nem anyanyelvi és a magyar közoktatásban dolgozó olasztanárok órai kommunikációjának színes spalettáját, megmutassa, milyen koncepciók, elképzelések, döntések állnak az egyéni megoldások mögött, amelyeket volt lehetőségem személyesen megfigyelni. A 8 középiskolában, összesen 11 tanórán készített hangfelvételek és az olasztanárokkal készített strukturált interjúk alapján szeretném vizsgálni a nem anyanyelvi olasztanárok spontán iskolai nyelvhasználatát.

A vizsgálatban részt vevő nyelvtanárok száma minden bizonnyal alacsonynak tekinthető, ugyanakkor a kutatás alapját óramegfigyelések is képezik, amelyek segítségével alkalmunk nyílik bepillantást nyerni a valós iskolai szituációkba, megvizsgálni, hogy az interjúkban megjelenő elképzelések és koncepciók a konkrét tanórai gyakorlatban is manifesztálódnak-e.

1 Köszönöm a budapesti Apáczai Csere János Gyakorló Gimnázium, Baár-Madas Református Gimnázium, Berzsenyi Dániel Gimnázium, Montessori Gimnázium, Szent Gellért Katolikus Gimnázium, Szent Imre Gimnázium, Toldy Ferenc Gimnázium és Xántus János Két Tanítási Nyelvű Gimnázium olasztanárainak, hogy részt vettek a kutatásomban: szeretettel fogadtak óráikon, és elhivatottsággal, időt és energiát szentelve válaszoltak minden kérdésemre az interjúk során. 


\section{Melyek a nem anyanyelvi tanár erősségei?}

A nyelvtanítás folyamatának fószereplői minden bizonnyal a tanulók és nem pedig a tanár, ugyanakkor ne felejtsük el, hogy az idegen nyelv csak és kizárólag a tanáron keresztül érhet el a tanulókhoz (Medgyes 1992). Nem kérdéses tehát, hogy a nyelvórai tanári beszéd továbbra is nagyon fontos kutatási terület. Tanulmányomban elsősorban, a nem anyanyelvi tanárok erősségeit szeretném kiemelni: az ELTE olasztanárképzésén szeretnék jó gyakorlatokat bemutatni a diákjaimnak, vagyis megmutatni nekik, hogyan lehet nem anyanyelviként is hatékonyan használni a tanári beszédet a nyelvórán.

Kétségtelen, hogy az anyanyelvi tanárok bizonyos szempontokból előnyt élveznek nem anyanyelvi kollégáikhoz képest, ezzel - amint a tanulmányban látni fogjuk - maguk a megkérdezett olasztanárok is pontosan tisztában vannak. A különböző kiindulási pontból adódó „hátrányt” nem egyszerű leküzdeni, még akkor sem, ha az ember motivált, eltökélt, kreatív és még számottevő tanítási tapasztalata is van (Medgyes 1992): az anyanyelvi és a nem anyanyelvi tanárok nem ugyanazokkal a nyelvi kompetenciákkal rendelkeznek. Medgyes (1992) meglátása szerint, aki a 90-es években elsőként kezdett komolyabban foglalkozni a nem anyanyelvi tanár témakörével, az idegen nyelvet tanulók - mint kezdetben maguk a nem anyanyelvi nyelvtanárok - nem rendelkeznek azzal a fajta nyelvi kreativitással, amely az anyanyelviek sajátja, illetve az anyanyelvi beszélők mindig is folyékonyabban, könnyedebben fognak megnyilatkozni, mint akik iskolában tanulják a nyelvet. Vannak azonban olyanok, akik másképpen gondolkoznak a témáról: Davies (2003) szerint az idegen nyelvet tanulók nyelvikompetencia-szintje elérheti az anyanyelvi beszélőét, ha sikerül elsajátítani olyan, elsősorban az anyanyelviekre jellemző készségeket, mint a nyelvi leleményesség, spontaneitás és kreativitás (Davies 2003; Moussu-Llurda 2008). A jelen tanulmány a következő kérdésre próbál választ találni: mely nyelvi készségek számítanak igazán, amikor az anyanyelvi, illetve a nem anyanyelvi beszélö úgy dönt, hogy iskolai keretek között tanítani szeretné az adott idegen nyelvet.

A nem anyanyelvi tanároknak nyelvtudásuk szintjén túl más nehézségekkel is meg kell küzdeniük. A célországon kívüli közoktatás keretei között zajló nyelvtanítás gyakorlatában a tanári beszéd központi szereppel rendelkezik: a diákok számára ez képezi ugyanis az egyedüli olyan nyelvi inputot a tanórán (és gyakran azon kívül is), ami direkt, tehát élő. Ugyanakkor az is alapvető fontosságú, hogy a tanulók, akik sokszor viszonylag alacsony nyelvi szinttel rendelkeznek, értsék a tanár kérdéseit, magyarázatait, instrukcióit. Nem véletlen, hogy számos nyelvtanuló számára bizonyos tanítási szituációkban akár nagyobb értékkel bírhat egy nem anyanyelvi tanár (Benke-Medgyes 2005; Moussu-Llurda 2008), aki egykor hasonló nyelvtanulási nehézségekkel küzdhetett.

Miután szemeszterről szemeszterre számos egyetemi hallgatóm bemutatóóráját látom, módszertani kurzusaim keretében sok-sok órát látogatok, illetve magam is tanítottam olaszt mint idegen nyelvet egy budapesti középiskolában, eredeti szilárd meggyőződésem a hatékony nyelvtanári kommunikációról kezdett meginogni. Elhatároztam, hogy 
alaposabban és fókuszáltabban fogom kutatni ezt a területet. 8 középiskolában jártam, ahol megfigyelhettem nyelvtanár kollégáim egyéni megoldásait, illetve az interjúk keretében irányított kérdések segítségével beszélgettünk is meglátásaikról. Kíváncsi voltam, szerintük melyek a nem anyanyelvi tanár erősségei, illetve szerettem volna személyesen megfigyelni jó gyakorlataikat.

A beszélgetés mindig egy egyszerünek tűnő kérdéssel indult, arra voltam kíváncsi, hogyan jellemeznék a jó nyelvtanárt, illetve megjelenik-e a válaszokban a nem anyanyelvi tanár nyelvi kompetenciájának kérdésköre.

A többségtől olyan válaszokat kaptam, mint:

A jó nyelvtanár...

(1) szereti a gyerekeket, hatékonyan közvetíti a célország kultúráját, hagyja szóhoz jutni a tanulókat, nyitott személyiség

Ezek mind nagyon fontos jellemzők. Érdekes, hogy egyetlen tanár említette: számára alapvető, hogy szaktudása, vagyis többek között nyelvtudása megközelítse az anyanyelviekét. A többség nem említette a nyelvi kompetenciát, ami számomra azért érdekes, mert a nem anyanyelvi tanár könnyen érezheti hátrányban magát nyelvtudása miatt anyanyelvi kollégáihoz képest. Amint már a tanulmány bevezető részében említettem, nem rendelkezünk az anyanyelvi beszélókével azonos szintủ nyelvi kompetenciákkal, készségekkel. Ezzel párhuzamosan - mint egy angol anyanyelvi tanárokkal foglalkozó kutatásból kiderül (Amin 2004; Moussu-Llurda 2008) - az anyanyelvi tanárok számára nem feltétlenül probléma, ha kisebb nyelvi hibákat ejtenek a nyelvórán, illetve ha nem ismerik részletekbe menően annak a nyelvnek struktúráját, amelyet tanítanak. A beszélgetések során világossá vált számomra, hogy a kutatásomban részt vevő tanárok számára, akik közül 5-en 10 évnél hosszabb tanítási tapasztalattal rendelkeznek, 3-an pedig 5 éven belül diplomáztak, a biztos nyelvtudás egyértelmű kiindulópont, ezért nem is érezték szükségét, hogy expliciten beszéljenek róla az interjúban.

Két tanártól részletesebb választ is kaptam $(2,3)$ a jó nyelvtanár ismérveit illetően, ezekből kitűnik a konkrét misszióval rendelkező nyelvtanár képe: egyikük szeretné az osztályterembe varázsolni Olaszországot, másikuk saját példájával, személyiségével szeretné motiválni diákjait.

(2) Ha ide belépnek, csak olasz van. Egy jó tanár élményként tudja átadni a nyelvet. A tanuló kösse azokat a dolgokat, amiket tanul, szituációhoz, emberhez. Nálunk vannak projekthetek, akkor is van mindig olaszos rész. Múlt évben volt a család téma, akkor behívtam egy olasz családot. Már a 9-esek is tudtak tőlük kérdezni. Helyzetbe kell hozni őket. De nem játszásból. Valós helyzeteket kell teremteni. Amikor a pénz volt a téma, akkor elküldtem őket az olasz ferencesekhez a Fő utcába, hogy csináljanak velük riportot. 
(3) Aki inspirálja a diákjait, aki példát tud mutatni. Csak olyan dolgokat csinálok az órán, amihez feltétlenül kell tanár. Például egy hallgatásértéshez kevésbé kell a tanár, ha el tudja érni azt, hogy otthon meghallgassák a szöveget. Ehhez kell persze, hogy inspiratív legyél, hogy meghallgassák a kedvedért. Az órámon csak olyan történjen, ami nélkülem csak nehezen történhetne meg: ilyen a beszéd. Nem várom, hogy a diákom otthon a tükörképével beszélgessen.

A továbbiakban a nem anyanyelvi tanár lehetséges erősségeit vizsgálom.

\subsection{A nyelvtanár mint nyelvi és kommunikációs minta}

Az anyanyelvi tanár kétség kívül nyelvi modellként szolgál a tanulóknak, alapvető erőssége a nyelvtudása (Diadori 2018): a formális, iskolai keretek között zajló nyelvoktatásban óriási pozitívum, ha a nyelvtanár személyében rendelkezésre áll ilyen autentikus nyelvi forrás. A magyar középiskolákban ugyanakkor leggyakrabban nem anyanyelvi tanárok oktatják a diákokat, ezért most vissza kell térnem a tanulmány elején megfogalmazott kérdéshez és a benne foglalt problémakörhöz, vagyis hogy milyen nyelven zajlanak a magyar közoktatásban az olaszórák. Egy magyar anyanyelvü olasztanár nagyon ritkán rendelkezik azzal a nyelvi kompetenciával, amellyel a célország beszélői, így nem is lehet velük egyenértékü nyelvi minta. Ezzel - a kapott válaszok alapján - a megkérdezett olasztanárok teljesen tisztában vannak, és nem is feltétlenül hátrányként tekintenek a diákokkal közös anyanyelvre:

(4) A kezdőkkel még figyelek, egyszerüsítek. Nyilván én jól tudok olaszul beszélni, nekem az lenne a legegyszerübb, ha én beszélhetnék olaszul, de nekem nincs szükségem a gyakorlásra: tehát ti fogtok beszélni. Rengeteg analitikus munka megy, az magyarul. Ugyanúgy elérem, hogy ők képesek legyenek olaszul megnyilvánulni. Engem az olasz-magyar óravezetés megakaszt, és én pont azt szeretném, ha minden flottul menne. Nem a tanári fordulatokat kell megtanulniuk. Mikor fogja ő azt mondani, hogy „aprite il libro ragazzi”, ez életszerütlen. Az instrukcióknál nincs jelentősége a nyelvnek, ez nem növeli érezhetően az ő nyelvtudásukat.

(5) Igyekszem olaszul tartani az órát. De vannak magyar részek. Ahogy megyünk elöre, igyekszem egyre kevesebbet magyarul. Szerintem a tökéletesen egynyelvü óravezetés lehet kontraproduktív. Van, aki egy idő után egyszerűen nem hallja meg az olaszt.

(6) Igyekszem olaszul. De inkább csak akkor, amikor eljutnak arra szintre, hogy élvezzék, csak akkor, amikor úgy látom, már ők is tudnak reagálni valamit. Tehát amikor már olaszul válaszolgatnak vissza, olaszul kérdeznek. Az óra 
elejét viszont mindig olaszul viszem: üljetek le, mi volt a lecke, mi volt elözö órán stb. A nyelvtan az inkább magyarul megy. Az instrukciókat is olaszul szoktam általában.

(7) A kicsiknél folyamatosan, tudatosan engedjük el a magyar nyelven történő magyarázatokat. Egyszerü igék, fónévi igenevek használatával. Azzal, hogy elismételtetem a feladatot, vagy valaki elmondja magyarul, segítjük azokat, akinek ez a készsége gyengébb. Nem szerencsés sokat magyarázni olaszul, ha nincs még egy alap tudásuk, ilyenkor elfogy a türelem és nem figyelnek oda, frusztrálódnak.

A válaszok összességéből kiderül, hogy a 8-ból 3 tanár tartja szinte kizárólag olaszul az óráit (2), valamint magam is 4 olyan órát láttam, ahol a tanár-diák kommunikáció döntő többsége olasz nyelven zajlott. A 8 megkérdezettből 5-en fontosabb szempontnak tartják, hogy a diákok teljességében értsék a tanár órai kommunikációját (4-7). Kivétel nélkül mindenki próbálja az adott csoport nyelvi szintjéhez igazítani saját iskolai nyelvét, ez pedig sok esetben azt jelenti, hogy a tanár gyakran, tulajdonképpen rendszeresen használja a magyar nyelvet az idegen nyelvi órán. Néhányan még azt is megemlítették, hogy diákjaik mennyire negatívan tudnak reagálni, amikor az idegen nyelvü tanári beszéd túl nehéznek bizonyul nekik (5), (7).

Összesen két válaszban utaltak rá, hogy az, hogy a tanár törekszik az idegen nyelvű óravezetésre pozitív hatással lehet a gyerekek nyelvi fejlődésére $(8,9)$.

(8) Ha magyarul mondok valamit, neki nem kell odafigyelni, nem kell résen lennie. Illetve hozzászokik, hogy végül is egymással magyarul is lehet beszélni. De nagyon nehéz csak olaszul, rá kell kényszeríteni a diákot, hogy próbálja megérteni. Nagyon oda kell figyelni, odafigyelek magamra, mert tudom magamról, hogy ellustulok. Amikor tényleg odafigyelek magamra, kontrollálom a beszédemet, hogy olaszul beszéljek, akkor tanulnak a gyerekek.

(9) Nálam becsukjuk az ajtót és itt nincs magyar. Ök próbálkoznak, de mondom: Non capisco. Azt gondoltam, mi van, ha azzal kezdjük, hogy élményeik vannak, hogy meg tudnak szólalni és majd utána mindent szépen elmagyarázok. A folyosón is nagyon vigyázok, hogy ne halljanak magyarul beszélni. A villamoson, ha találkozok velük, ott is megszólalnak, nyökögnek, de élvezik, hogy olaszul kell.

Fontos kiemelni, hogy még ha csak kevesen is vezetik végig olaszul az olaszórát, mindenki egyetért abban, hogy az órák első percei döntő fontosságúak, ezért ekkor kivétel nélkül mindenki olasz nyelven fordul a diákjaihoz. 
Az egyes számú függelékben három különböző órakezdés átiratát szeretném bemutatni három fenti vélemény alátámasztásául (4), (7) és 8).

Az első két esetben [lásd: 1a melléklet + (4) és 1b függelék + (7)] a tanár tudatosan váltogatja a közös anyanyelvet, vagyis a magyart, illetve a célnyelvet. Egyrészről fontos szem előtt tartani, hogy az olaszt az angol után második idegen nyelvként átlagosan heti 3-4 órában tanítjuk, és csak a középszintű oktatás 4-6 éve alatt. Sokan úgy gondolják, a cél inkább az, hogy a tanulók megszeressék az idegen nyelvet, és a középiskolai évek lezárulta után önszántukból, önállóan is tovább fejlesszék nyelvi kompetenciájukat. A 4-es számú válaszban egy más szempont is megjelenik: sok nyelvtanár fontosnak tartja, hogy maximálisan kihasználja a kontrasztív megközelítés kínálta lehetőségeket. A kontrasztivitás több esetben segíthet megérteni a magyar anyanyelvű nyelvtanulóknak bizonyos nyelvtani elemek, szerkezetek müködését az olasz nyelvben. Előfordul, hogy nem is a tanulók anyanyelvét hívjuk segítségül, hanem a nyelvi jellegzetességeiben az olaszra jobban hasonlító angol nyelvet. A harmadik esetben [lásd: 1c melléklet + (8)] másfajta tanári attitűdöt fedezhetünk fel: a tanár tudatosan erőlteti az olasz nyelvű tanári beszédet, ennek következményeként, tulajdonképpen cserében a diákok is igyekeznek olaszul kommunikálni az órán. Nem elvárás, hogy hibátlanul fejezzék ki magukat az idegen nyelven, amikor szabadon beszélnek, a cél inkább az, hogy hozzászokjanak az idegen nyelvű megnyilvánulásokhoz.

Összességében tehát megállapítható, hogy a nem anyanyelvi tanároknak nem feltétlenül az a küldetésük, hogy nyelvi mintaként szolgáljanak a tanulók számára. Ugyanakkor fontos megjegyezni, hogy a megkérdezett olasztanárok döntő többsége nem tért ki erre a problémakörre, vagyis nagy valószínűséggel ez a tényező nincs komoly befolyással szakmai önértékelésükre.

Más a helyzet a tanárjelölt hallgatók esetében, akik a képzésük hat éve alatt párhuzamosan fejlesztik szaktárgyi, vagyis ebben az esetben idegen nyelvi készségeiket, kompetenciáikat, illetve szakmódszertani tudásukat. A kezdő nyelvtanároknak kiemelten fontos lenne, hogy első szárnypróbálgatásaikat a tanári pályán ne nehezíthessék meg nyelvi hiányosságaik. Az egyes nyelvtanári szakokon a hallgatóknak magas szintű szaktól függően C1-C2-es - nyelvi záróvizsgát kell tenniük: elméletileg ennek teljesítése a garancia arra, hogy a leendő nyelvtanárok biztos nyelvi tudással rendelkeznek, amikor a tanítási gyakorlatok keretében belépnek a középiskolai közegbe.

\subsection{A nyelvről való gondolkodás és a nyelvi szerkezetek magyarázatának képessége}

Ami a nyelvi készségeket illeti, az anyanyelvi tanárok kétségtelenül előnyt élveznek nem anyanyelvi kollégáikhoz képest, a nyelvismeret, nyelvi tudatosság és a nyelvi tudatosság átadásának - legalább is annak egy részének - képessége azonban pont a nem anyanyelviek erősségeit képezhetik. Minden, a kutatásban részt vevő olasztanár egyetértett abban, hogy az idegen nyelv tanulása folyamán a diákokkal közös anyanyelv mintaként szolgál, és ezért fontos használni, sőt egyenesen használni kell, amikor a diákokkal az idegen nyelvről gondolkodnak, amikor az új nyelvi ismereteket rendszerezik. 
Phillipson (1992, vö. még Moussu-Llurda 2008) is hasonló véleményen van a nem anyanyelvi tanárok lehetséges erősségei kapcsán: véleménye szerint akik felnőttként, illetve fiatal felnőttként, vagyis formális, iskolai kontextusban tanulták az idegen nyelvet, felkészültebbek a célnyelv tanításában, mint azok, akik gyerekként sajátították el. Barratt-Kontra (2000) arra mutattak rá, hogy egyes esetekben az anyanyelvi tanárok akár meg is akaszthatják tanulóikat a nyelvtanulás folyamatában, amennyiben nem tudnak kontrasztív jellegű magyarázatokkal, példákkal szolgálni, illetve ha nem fordulnak kellő érzékenységgel diákjaik esetleges problémái felé, akik a formális nyelvtanulás rögös útját járják.

Az interjúk alapján abban viszont nem teljes az egyetértés, hogy a nyelvtani magyarázatokat milyen nyelven kellene adni, illetve milyen nyelven kellene közvetíteni a nyelvi tudatosságot a diákok felé:

(10) A nyelvtant sosem magyarázom olaszul, nem vagyok hajlandó. Néha azt gondolom, hogy olaszul is el kellene magyarázni, de a csoportjaim nem homogének. Túl sok időt venne igénybe olaszul.

(11) Én nem is tudnék anélkül tanítani, hogy nem azonos az anyanyelvem a diákokéval. Jó, tudnék dolgozni, csak sokkal több órára lenne szükségem ahhoz, hogy ugyanarra a szintre jussak. Az, hogy van egy közös nyelvünk, nagyon felgyorsítja a tanítási folyamatot, arra lehet hivatkozni, össze lehet vetni a dolgokat a két nyelvben. Itt az a nehézség, hogy el is kell tőle tudni rugaszkodni.

(12) A nyelvtant magyarul szoktam, hogy mindenki megértse. Olaszul is mondom, és ismétlésnél használom ezeket a kifejezéseket olaszul. Időt spórolok meg azzal, ha magyarul mondom. Ki kell használni az olasz-magyar és olasz-angol kontrasztív magyarázatokat.

(13) Nyelvtani magyarázatnál, szavaknál nagyon hasznos tud lenni a magyar nyelv. Lehet, hogy kettő felfogta, de ha magyarul elmondjuk, mindenki számára világos lesz.

(14) Amikor odafigyelek magamra, kontrollálom a beszédemet, hogy olaszul beszéljek, akkor tanulnak a gyerekek. Nagyon sokat. Ha az én számból hallja, hogy penso che és utána egy congiuntivo, vagy se... de ehhez a tanár részéről nagyon nagy önfegyelem kell, hogy ezt tartsa.

A magyar nyelvű nyelvtani magyarázatok védelmében a tanárok több tényezőre utalnak: az időre (10), (11), a csoportok heterogeneitására mind a nyelvi szintet, mind a nyelvről való gondolkodás képességét és következés képen a tanulók különböző igényeit 
tekintve (10), (12), (13). Ezek mellett többen megemlítik a kontrasztív megközelítésben rejlő lehetőségeket (11), (12), és nem utolsó sorban azt, hogy egy magyar anyanyelvű tanárnak nem minden megerőltetéstől mentes idegen nyelven adnia a nyelvtani magyarázatokat, illetve idegen nyelvi mintaként funkcionálnia (14).

Egy más megközelítést sugalló válasz is elhangzott (15):

(15) Van olyan óra, amikor érzem, hogy többször meg kell szólalni magyarul, főleg a nagyobbaknál, amikor a bonyolultabb részekhez jutunk. Addig szoktam csak olaszul, amíg érzem, hogy értik. Ha nem is $100 \%$-ig, de megértik, amit mondani akarok. Úgy jellemzően 9. év áprilisáig kihúzom így.

Meglátása szerint föleg a nyelvtanulási folyamat elején a tanulók többet nyernek azzal, ha „helyzetbe vannak hozva”, próbálkozhatnak használni a nyelvet, és nem bonyolult nyelvtani magyarázatokat hallanak a nyelvröl, amelyek - pont az alacsony nyelvi szint miatt - nagy valószínűséggel magyarul lennének. Ennek megfelelően itt a gyerekek a legeslegelső pillanattól kezdve olasz nyelvi környezetben vannak, ami magában foglalja az olasz nyelvű tanári beszédet is. Példák és egyszerủ olasz nyelvű magyarázatok segítségével meg lehet ismertetni a tanulókkal az alapszintủ nyelvi elemeket, amelyek segítségével kezdetektől átélhetik a nyelv valós használatának élményét.

A nem anyanyelvi tanárok nyelvtanítási gyakorlatában megfigyelhető különbözőségek alátámasztásául függelékben olvasható (lásd: $2 \mathrm{a}$ és $2 \mathrm{~b}$ melléklet) két nyelvóra néhány pillanatának átirata, amelyeket a 11-es és a 15-ös választ adó nyelvtanár kollégák tartottak.

\subsection{A nyelvtanár mint nyelvtanulói modell}

A kapott válaszokból végül még egy nagyon fontos aspektus előkerül: a nem anyanyelvi tanár mint tanulói modell is: nem csupán abban lehet minta tehát, hogyan kell az idegen nyelvet használni, de abban is, hogyan kell megtanulni (Medgyes 1992). Idegennyelvtanulási stratégiákat tudnak átadni a tanulóknak, olyan stratégiákat, amelyeket saját nyelvtanulási folyamatuk során sajátítottak el.

A következő (16-18) válaszok a tanári viselkedésnek pontosan erre, az úgynevezett tanulói modell aspektusára világítanak rá. Kramsch (1997) (Moussu-Llurda 2008) úgy véli, nem jó, ha a nem anyanyelvi tanárok az anyanyelviekkel szemben meghatározott elvárásoknak próbálnak megfelelni, sokkal kifizetődőbb, ha nem anyanyelviként találják meg a saját hangjukat, akik nyelvtanulóként szerzett tapasztalataiknak köszönhetően segíthetik a tanulókat.

(16) Tudjuk, hogyan működik a magyar agy. Elég szisztematikusan. Emlékszem, én is mikre akartam rájönni, amikor tanultam a nyelvet. 
(17) Átérzem a nehézségeket, mert anno ugyanúgy meg kellett velük küzdenem (pl. elöljárók, névmások, egyeztetések, rendhagyó igék). A gondolkodásmódunk is más, mint az olaszoké.

(18) Én például nem voltam egy nyelvzseni, voltak nagy koppanások, talán jobban tudom felmérni, hogy mi az, ami egy magyar gyereknek az olaszban nehézséget okoz. Talán jobban tudom egyszerüsíteni a szabályokat, ami nekem is segített volna.

Az utolsó válasz (19) pedig arra utal, hogy az órai tanári attitűd is lehet példaértékű a tanulóknak. Nem vonatkoztathatunk el attól az alapvető igazságtól, hogy egyrészt az órai idegen nyelvű input mennyisége, másrészt az idegen nyelven való gondolkodás képességének megmutatása hatással van a tanulók nyelvi készségeinek fejlődésére.

(19) Itt az a nehézség, hogy el kell tudni rugaszkodni a magyartól. Hogy mennyire szabad hozzá közel menni, ezt a tanárnak kell tudnia menedzselni. Ha ezt kiengedi a kezéből, és hagyja, hogy állandóan fordítások legyenek, az óriási nehézséget okozhat a passzív készségek fejlesztésében. Mert akkor a diákok azt gondolhatják, hogy csak úgy érthetik meg a szöveget, ha szóról szóra lefordítják. Nagyok tehát a veszélyei ennek.

\section{3. Összegzés}

Medgyes (1994) szerint a magyar közoktatásban dolgozó nem anyanyelvi tanár erősségei általában a következők: képes órai nyelvhasználatát a tanulók nyelvi szintjéhez igazítani, jól ismeri a célnyelvet, képes a nyelvről, a nyelvhasználatról gondolkozni és magyarázatokat adni - esetenként kontrasztív megközelítésben is -, képes a tanulókat vezetni, kísérni a nyelvtanulás folyamatában, köszönhetően egy tág eszköz- és módszertárnak, amelyre az egyetemi szintű tanárképzés során tett szert. De melyek azok a képességek, amelyeket fejleszteni kellene? A megkérdezett nyelvtanárok saját bevallása szerint nem anyanyelviként a C1-es, C2-es szintű csoportok tanítása okozhat nyelvi nehézségeket. Szakmódszertanos oktatóként számos gyakorlóiskolában megtekintett bemutatóóra után hasonló tapasztalatokkal rendelkezem: a nem anyanyelvi tanárjelöltek gyakran strukturáltabb ismeretekkel rendelkeznek a célnyelvről, mint akár anyanyelvi kollégáik, ugyanakkor kezdetben érdemesebb alacsonyabb nyelvi szinttel rendelkező csoportokban kipróbálniuk magukat.

De a nyelvtudás fejleszthető, és egy nyelvtanárnak kötelessége is állandóan fejleszteni, vagy akár szinten tartani: a szókincs, a kifejezésmód gördülékenysége, választékossága fejleszthető. Ami viszont annyira nem, az az autentikussága. Az autentikusság tűnik tehát a legalapvetőbb „problémának”. Nem vagyunk és nem is leszünk anyanyelvi beszélői 
az idegen nyelvnek, amit tanítunk. Ugyanez a „probléma” merül fel a célországi kultúra közvetítése, tanítása kapcsán is: egész egyszerűen nem vagyunk szerves részei a kultúrának, amit beviszünk az órára. A nyelvtanárok változatosan reagálnak erre a kérdéskörre. Van, aki egész egyszerűen azt mondja:

(20) Én sajnálom az időt a kultúra közvetítésére az órán. Nekem a nyelv az elsődleges. És azzal majd ők a kultúrát felfedezik. Ehhez nem feltétlen kell a tanár. Csak olyan dolgokat csinálok az órán, amihez feltétlenül kell tanár. Ha ők a nyelvet jól megtanulják, márpedig jól megtanulják, akkor ők a mai világban úgy szedik fel a kultúrát, ahogy csak akarják. Persze adok nekik támpontokat.

Amint láttuk: van, aki olasz családot hív meg az óráira, illetve a tanulók Budapesten élő olasz ferences szerzetesekkel készítenek interjút. Van, aki rendszeresen olvassa az olasz sajtót, olasz videókat néz napi szinten, és minden évben kimegy pár napra Olaszországba, hogy felfrissítse a benyomásait, amiket aztán közvetíteni tud. Végül van, aki feladatának érzi, hogy neveljen is, ugyanis ez a gimnazisták személyiségfejlődésének egy fontos szakasza:

(21) A kultúra közvetítője is vagyok, sok mindent megtanítok. A legaljáról kell kezdeni a dolgokat. Például ma azt kellett megtanítanom, hogy mi az a Vízkereszt, vagy kik voltak jelen a jászolnál Jézus születésekor.

Mi, nem anyanyelvi tanárok gyakran érezhetjük magunkat hátrányban az anyanyelvi kollégákhoz képest. A vizsgált középiskolai közegben viszont az autentikusságon túl (ami gyakran nincs jelen) más tényezők is számítanak, amelyek bátoríthatják a nem anyanyelvieket: először is a diákok életkora, akiknek még igenis szükségük van egy vezetőre (a nyelvórán is), vagy a nyelvi szint, amely általában az A1 és a B2 között mozog. Ez persze nem azt jelenti, hogy a tanárnak direkt alacsony szinten kell beszélnie a diákokhoz, hanem azt, hogy nagyon tudatosnak kell lennie a nyelvhasználatában. Ez pedig egy jó kiindulópont a minőségi oktatás garantálásához.

\section{Irodalom}

Amin, Nuzhat 2004. Nativism, the native speaker construct, and minority immigrant women teachers of English as a second language. In: Kamhi-Stein, Lia (ed.). Learning and teaching from xperience. Michigan: University of Michigan Press. 61-90.

Barratt, Leslie - Kontra Edit 2000. Native-English-Speaking teachers in cultures other than their own. TESOL Journal 9/3: 19-23.

Benke Eszter - Medgyes Péter 2005. Differences in teaching behaviour between native and non-native speaker teachers: As seen by the learners. In: Llurda, Enric 
(ed.): Non-Native Language Teachers. Boston: Springer. 195-216. https://doi. org/10.1007/0-387-24565-0_11

Davies, Alan 2003. The native speaker of World Englishes. Journal of Pan-Pacific Association of Applied Linguistics 6/1: 43-60.

Diadori, Pierangela 2018. Punti di forza e di debolezza del docente nativo. Il caso dell'italiano L2. Italiano a stranieri 23: 3-8.

Kramsch, Claire 1997. The privilege of the non-native speaker. PMLA 112/3: 359-369.

Medgyes Péter 1992. Native or non-native: who's worth more? ELT Journal 46/4: 340349. https://doi.org/10.1093/elt/46.4.340

Moussu, Lucie - Llurda, Enric 2008. Non-native English speaking English language teachers: History and research. Language Teaching 41/3: 315-348.

https://doi.org/10.1017/S0261444808005028

Phillipson, Robert 1992. Linguistic imperialism. Oxford: Oxford University Press.

Vörös Anna 2004. Osztálytermi kommunikáció, tanár-diák interakciók. In: N. Kollár Katalin - Szabó Éva (szerk.): Pszichológia pedagógusoknak. Budapest: Osiris Kiadó. 395-417.

\section{Mellékletek}

\section{1a: órakezdés}

T: Oggi manca Benedek. Sappiamo qualcosa di Benedek? Sapete dove è, o perché non è venuto?

D1: È malato.

T: OK. Ieri hai parlato con lui via messenger?

D1: Via messenger.

T: Gli hai mandato tutti i compiti di italiano?

D1: No, ma ... Lui ha mangiato qualcosa, e lui è ...

T: che gli ha fatto male. Gli fa male lo stomaco? Questa parte qui [NVK a tanár a hasát mutatja]. Ok. E come state stamattina ragazzi? Non dovete cantare però. Andrea voleva cantare perché sapeva che saresti venuta tu [NVK mosolyog]. Allora Tamara come stai? D2: Sto molto bene ... no, sto male. Avevamo l'educazione fisica.

T: E non ti è piaciuta la lezione di sport?

D2: No, non mi piace l'educazione fisica, quando è la prima lezione.

T: Blanka, tu, come stai stamattina?

D3: Sto bene.

T: Benissimo.

D3: Oggi, stamattina, sono partito solo dopo sette e mezzo, sì, perché si è rotto la mia mano e non dovevo andare alla lezione di educazione fisica.

T: il braccio ... sì ... Nóri? 
D4: Non ho dovuto andare all'educazione fisica, perciò ho potuto mangiare colazione con Ági.

T: Aaa, questa è la vostra abitudine già dall'anno scorso, che andate a fare colazione insieme, bene, bene. Dove siete andate?

D4: A *Jászai Mari tér.

T: Alla Piazza Jászai. Hai fatto una colazione abbondante?

D4: No, un panino. E non ho bevuto niente.

T: E Tomi, tu?

D5: Oggi non ho fatto niente di interessante. Solo stamattina ho dormito un po' più di solo, ... di solito, perché ieri arrivavo a casa molto molto tardi, perché ieri avevo una lezione di chitarra e dopo dovevo andare al dottore e perciò posso ritornare a casa molto tardi.

\section{1b: órakezdés}

T: Ho notato che non tutti me l'avete consegnato. Forse, avete frainteso la regola. Non sono chiare le regole. Vi ricordate della regola della quantità, che devono essere riempite due pagine? MA ... [Két lány a csengetés után ér be az órára.] E voi dove siete state? Educazione fisica?

D1: Ho dovuto aiutare il nostro *cserediák.

T: il mio partner di scambio. Aiutare a fare che cosa?

D1: Le ho chiesto *ööö... dove *ööö... la sua lezione *ööö... sarà.

T: Dove sarà la sua lezione. Perché adesso stanno assistendo a delle lezioni?

D1: Sì.

T: E loro sono adesso presenti a scuola ... ma io non ho visto nessuno. In: quanti sono?

D1: Due.

T: Di quanti studenti è il gruppo di scambio? Ma sono gli svizzeri?

D2: Noo.

$\mathrm{T}$ : Ah, ... ma state parlando del vostro compagno di classe. Credevo che tu... ${ }^{*} \mathrm{Na}$, mit is hittem én? Tessék lefordítani a gondolatomat. Azt hittem, hogy egy svájci cserediákról beszél.

D3: ... La professoressa credeva che parlasse del suo partner di scambio.

T: OO, [Még egy diák érkezik késve.] ANCHE TU DOVRAI GIUSTIFICARTI DEL TUO RITARDO. ... E, a proposito. Forse anche voi partecipate ad uno scambio. Se avrò notizie nuove,... e sì, volevo dirvi che ..., voglio annunciarvi questo fatto che forse si farà questo scambio. Non so in quanti vorrete partecipare. Pensateci. Poi, se avrò notizie più precise, allora tornerò su questo argomento. Vi rifarò la domanda. Bene. Allora stavi dicendo...

D1: Il mio compagno di classe che si chiama Anna e lei abita in Argentina e ora non ha nessuna lezione, ma io non avevo saputo.

T: Non sapevo,... forse. 
D1: Non sapevo, perciò le ho chiesto se lei ha una lezione ora o no.

T: E dovevi accompagnarla da qualche parte. Vi siete fermate a parlare, se ho capito bene.

D1: Dovevo aiutarla, ma non ogni volta, perché lei sa ... *ööö ...

T: È riuscita ad ambientarsi? *Hogy lenne az, hogy: azt hittem, hogy a teremhez kísérte? Zsombor?

D5: Credevo che ce l'avesse accompagnata.

\section{1c: órakezdés}

T: *Felszerelés? Quaderni? Va bene, ora giochiamo. Facciamo un gioco. Cosa abbiamo studiato? Che cosa abbiamo studiato? Bogi? Studiare?

D1: tanulni

T: *Aha. ABC in italiano?

D: ...

T: Alfabeto. Ok. Per favore.. Lei si chiama Alma, una mia collega, ... presentatevi. Nomi. Io mi chiamo Ági. Tu, per favore, PRESENTATI ad Alma. Come ti chiami?

D1: Mi chiamo Bogi.

$\mathrm{T}$ : Zsolt, come ti chiami?

D2: ... [Eltelik egy perc csendben.]

T: Zsolt, mi chiamo Ági. Come ti chiami? *A nevedet szeretnénk hallani ...

D2: ... [Eltelik majdnem még egy perc csendben.]

T: Ok, ... Gergö, per favore. *Az a kérdés, hogy ... Come ti chiami?

D3: Mi chiamo Gergő.

T: Ok. Abbiamo studiato l'alfabeto. No? Alfabeto. Alziamoci in piedi! TUTTI. In: piedi! [NVK, a tanár feláll, és mutogatva kéri a diákokat, hogy ők is álljanak fel]. Alziamoci! E lanciamo la palla. Lanciamo la palla. Lanciare significa questo [NVK úgy tesz, mintha eldobna valamit]. Facciamo un cerchio. Ok cerchio significa ... [NVK a karjaival egy kört formáz]. Cerchio?

D4: *kör

T: *Széket toljuk be, oké? Perché ci danno fastidio. Io lancio la palla e io dico A. [A tanár eldobja a labdát.]

D5: A come Ancona.

T: Anna, e tu dici? Io dico A. E tu dici?

D5: B. B come Bologna.

T: *Aha, ok, lancia la palla. Lancia la palla.

D6: C come Como.

$\mathrm{T}$ : Ok, lancia la palla. Lancia.

D7: D come Domodossola.

T: Ok, grazie. Adesso facciamo il gioco dei numeri. Andiamo in giro. Anche tu Gergő, per favore. Andiamo in giro e comincio io, UNO. 
DD: Due, tre, quattro, ... [A játék megáll.]

T: Uno.

DD: Due, tre quattro, cinque...

\section{2a: nyelvtani magyarázat}

T: Adesso impariamo un'altra cosa nuova. Come si chiama il nostro paese? [Európatérkép, rajta az országnevek olaszul] Dove siamo adesso. Quindi impariamo una cosa nuova oggi. Sarà la provenienza. Come si chiama il nostro paese?

D1: Ungheria.

T: Ok. Io e tu siamo ungheresi. Quindi le persone che vivono in questo paese si chiamano ungheresi. Cioè Matteo è ungherese. Io sono ungherese. Rita tu sei ungherese? Sei ungherese?

D2: Sì.

T: Sì, sei ungherese. Ok. [A tanárnak ki kell mennie az óráról pár percre.]

D3: *Én nem értem.

D4: *Ỏ mutatja a térképen, hogy Magyarország és aztán mondja, hogy magyar vagyok.

Mit nem értesz ezen?

D3: *Jaa.

[A tanár visszajön.]

T: Scusate. Allora l'Ungheria, va bene. L'Italia? Come si chiamano le persone che vivono in Italia? Una persona che vive qui [Megmutatja Olaszországot a térképen.]. Come si chiama questa persona?

DD: italiano

T: Italiano. Bravisssimi. [ $\mathrm{T}$ italiano] Uno che abita in ... [A tanár megmutatja Franciaországot a térképen.] come si chiama questo paese? La ...

D5. Franca.

T: La ... Francia. Chi abita qui, è francese. Francese. Come si chiama questo paese? [Megmutatja Spanyolországot.]

DD: Spagna.

T: Come si chiama chi abita qui? Spagnolo. Uno che vive in Slovenia? Sloveno.

Slovacchia? Slovacco. Svizzera? Svizzero. Germania? Questo è difficile. Tedesco. Per ora basta così. Possiamo ripetere un attimo? Ungheria, ungherese.

DD: Ungheria, ungherese.

T: Italia, italiano.

DD: Italia, italiano.

T: Se io sono... mettiamo che Mattia è italiano. Io invece sono italiaaa...

DD: ... na

T: Sì, io sono italiana. Rita è italiana. Anna è...

DD: italiana

T: Antonio 
DD: italiano

T: Bravi.

\section{2b: nyelvtani magyarázat}

T: *Itt, ebben a szövegben vannak kötőszavak, ugye a kötőmódot vonzó kötőszavak. Múltkor kellett írni nonostante che-s mondatokat. Azokat tessék fel is olvasni, mert ezekre már nem szeretnék visszatérni. Na most, alzi la mano chi non ha scritto frasi con nonostante che. Solo Tomi? Voi tutti avete delle frasi? Dovevate scriverle durante la lezione. Invece voi avete scritto? Anche una ... con nonostante che. *Akinek megvan, olvassa fel, akinek nincs, az most gyártsa le!

D1: Nonostante che glielo abbia spiegato, non lo capiva.

T: *Aha. Mi itt a főmondat? Még egyszer kérjük.

D1: Nonostante che glielo abbia spiegato, non lo capiva.

T: *A non lo capiva a fömondat. Légy szíves visszhangozd az Enikőét! Javíthatsz rajta, ha gondolod. Módosíthatsz.

D2: Nonostante che ... glielo abbia spiegato, non lo ... capiva.

T: *Na, hogyha megnézitek a táblázatot, akkor ezt nem dobja ki, ezt a mondatot. Mert hogyha a fómondat múlt idejü, akkor? Az abbia spiegato-t ha megnézitek a táblázatban, akkor biztosan látjátok, hogy a fömondat nem múlt idejü.

D3: ... avesse capito ...

T: *jó, akkor avesse capito. *Akkor, hogy lesz helyesen, Enikő?

D1: Nonostante che glielo avesse spiegato, non lo capiva.

T: *Igen, vagy continuava a non capirlo. *Hogy lenne ez jelenidőben, Luca?

D4: ... Nonostante che glielo abbia spiegato, non sono riuscita a ...

T: *Hát, ha megint egy múlt idejü fömondatot mondasz... Akkor vissza az egész, megint avesse-t kellene mondani. Non capisce, vagy continua a non capire. Jó? Jelen idejü fömondat kell. 